\title{
HUBUNGAN ANTARA KETERAMPILAN METAKOGNISI DENGAN HASIL BELAJAR KONSEP MOL
}

\author{
Rini Wijayantia , Suhadi Ibnu ${ }^{b}$, Muntholib $^{c 1}$ \\ a,b,cJurusan Kimia FMIPA Universitas Negeri Malang
}

\begin{abstract}
Abstrak - Metakognisi adalah kemampuan berpikir seseorang di mana objek berpikirnya adalah dirinya sendiri. Tujuan penelitian ini adalah mengetahui keterampilan metakognisi, hasil belajar Konsep Mol, dan hubungan antara keterampilan metakognisi dengan hasil belajar Konsep Mol peserta didik peserta didik SMA Negeri 2 Mejayan Madiun. Penelitian ini merupakan penelitian korelasional. Instrumen yang digunakan dalam penelitian ini adalah soal subjektif tes hasil belajar Konsep Mol dan Metacognitive Awareness Inventory (MCI). Hasil penelitian menunjukkan bahwa 1) skor rata-rata keterampilan metakognisi peserta didik adalah 73,68; 2) Skor rata-rata hasil belajar Konsep Mol peserta didik adalah 58,87; dan 3) terdapat hubungan yang kuat antara keterampilan metakognisi dengan hasil belajar Konsep Mol peserta didik dengan koefisien korelasi 0,609.
\end{abstract}

\section{Kata kunci: Metakognisi, Hasil belajar, Konsep mol}

\begin{abstract}
Metacognition is thinking about thinking. The purpose of this research is to know the students' metacognition skills, students' achievement of Mole Concept, and the relationship between students' metacognition skills with their achievement. This research applied correlational design. The instruments used in this research are Essay Mole Concept Assessment Test and Metacognitive Awareness Inventory (MCI). The results of this study indicate that 1) the average score of students' metacognition skills is 73.68;2) Average score of student achievement of Mole Concept is 58,87; and 3) there is correlation between students' metacognition skill with their achievement of Mole Concept with correlation coefficient 0,609.
\end{abstract}

Keywords: Metacognition, Achievement, Mole Concepts

\section{PENDAHULUAN}

Salah satu masalah utama pendidikan adalah rendahnya kualitas pendidikan yang tercermin dalam capaian belajar peserta didik yang dikenal dengan nama prestasi belajar. Hasil-hasil penelitian menunjukkan bahwa hasil belajar kimia peserta didik masih rendah. Eronika (2012), Rahayuningsih dkk. (2012), dan Rohaenitasari (2013) menunjukkan bahwa prestasi belajar peserta didik rata-rata berkisar antara 50-69 dari

\footnotetext{
${ }^{1}$ Corresponding authors: Muntholib, Program Studi Pendidikan Kimia, Universitas Negeri Malang, Jl. Semarang No. 5 Malang 65145, Indonesia. Email: muntholib.fmipa@um.ac.id
}

ISSN: 2528-6536 (cetak)/ISSN: 2579-5945 (online)

@2017 J-PEK 
skala hasil belajar 0-100. Keadaan ini juga terjadi di SMA Negeri 2 Mejayan Madiun. Hasil belajar kimia peserta didik SMA Negeri 2 Mejayan Madiun berkisar antara 50-70 dari nilai maksimum 100, dan hasil belajar 65\% peserta didik dibawah 55 (Utomo, personal comunication, 2015).

Menurut Depdiknas (2007), hasil belajar yang rendah salah satunya disebabkan oleh rendahnya tingkat pemahaman peserta didik terhadap materi pelajaran yang dipelajarinya. Hal ini disebabkan oleh rendahnya kesadaran peserta didik untuk belajar atau metakognisi. Metakognisi (Livingstone, 1997) adalah thinking about thinking. Metakognisi merupakan kemampuan berpikir seseorang yang objek berpikirnya adalah dirinya sendiri atau suatu proses berpikir di mana yang menjadi bahan pikiran adalah diri orang yang berpikir itu sendiri. Metakognisi diperlukan oleh peserta didik dalam pembelajaran. Peserta didik dikatakan memiliki keterampilan metakognisi yang baik apabila dalam proses pembelajaran terbiasa dengan strategi metakognisi.

Menurut Kaberman \& Dori (2008) strategi metakognisi merupakan salah satu komponen dari metakognisi yang didefinisikan sebagai strategi umum yang digunakan ketika seseorang belajar, berfikir, dan memecahkan masalah. Strategi ini akan berguna bagi proses perencanaan, memantau (monitoring), dan mengatur proses belajar dan berfikir yang peserta didik lakukan. Strategi metakognisi oleh ivingstone (1997) disebut juga dengan istilah keterampilan metakognisi.

Keterampilan metakognisi dibagi menjadi tiga komponen yaitu planning skill, monitoring skill, dan evaluation skill (Livingstone, 1997). Hal senada diungkapkan oleh Young \& Fry (2008) bahwa terdapat tiga komponen dalam keterampilan metakognisi yaitu planning (perencanaan), monitoring (pemantauan), dan evaluation (penilaian). Menurut Harford Community College (2014) keterampilan metakognisi berkaitan dengan perencanaan, implementasi strategi, monitor, meluruskan pemahaman yang salah, dan melakukan evaluasi terhadap pembelajaran yang seseorang lakukan.

Apabila ketiga komponen tersebut dapat dilakukan dengan baik maka proses regulasinya akan berjalan dengan baik. Hal ini akan berdampak pada proses berpikir seseorang yang akan lebih terstruktur dan lebih fungsional. Akibatnya hasil belajar yang diperoleh peserta didik akan naik. Hasil belajar adalah capaian akademik yang diperoleh peserta didik melalui proses pembelajaran yang berlangsung dalam waktu tertentu dalam mempelajari suatu materi pelajaran. Mathabathe \& Potgieter (2014) mengungkapkan bahwa keterampilan metakognisi dapat membedakan antara pembelajar yang baru memulai (novice learner) dengan pembelajar yang sudah ahli (expert learner).

Hasil dari beberapa penelitian telah membuktikan bahwa metakognisi itu berhubungan dengan hasil belajar. Hasil penelitian Iin dan Sugiarto (2012) menjelaskan adanya keterkaitan yang sangat erat antara keterampilan metakognisi dengan hasil belajar dan keduannya merupakan satu rangkaian yang tidak terpisahkan. Hal selaras diungkapkan oleh Nuryana dan Sugiarto (2012) yaitu terdapat keterkaitan yang erat antara keterampilan metakognisi dengan hasil belajar karena hasil belajar merupakan suatu hasil dari proses kognisi. Kedua hasil penelitian ini dikuatkan oleh penelitian dari Rahman dan Phillips (2006) yang mengungkapkan bahwa terdapat hubungan yang positif serta signifikan antara keterampilan metakognisi dengan pencapaian akademik 
pelajar. Penelitian yang dilakukan ini berguna untuk melakukan verifikasi terhadap hasil penelitian sebelumnya.

Konsep mol merupakan salah satu materi pelajaran kimia. Materi konsep mol berisi pemahaman konseptual dan pemahaman algoritmik. Materi yang di dalam konsep mol antara lain adalah massa atom relatif $\left(\mathrm{A}_{\mathrm{r}}\right)$, massa molekul relatif $\left(\mathrm{M}_{\mathrm{r}}\right)$, massa molar, jumlah zat, jumlah partikel, volume molar gas. Karekteristik materi konsep mol memiliki kecocokan dengan komponen dalam keterampilan metakognisi yang meliputi planning skill, monitoring skill, dan evaluation skill. Berkaitan dengan hal tersebut, untuk mengetahui apakah keterampilan metakognisi juga berhubungan dengan konsep mol, dilakukan penelitian dengan judul "Hubungan antara Keterampilan Metakognisi dengan Hasil Belajar Konsep Mol Peserta didik Kelas X SMA Negeri 2 Mejayan Madiun”.

\section{METODE}

Penelitian ini merupakan jenis penelitian studi kasus dengan menggunakan metode penelitian deskriptif korelasional. Penelitian jenis ini hanya melihat seberapa jauh hubungan antar variabel tanpa melihat adanya sebab-akibat. Variabel yang akan dicari korelasinya adalah variabel keterampilan metakognisi dan variabel hasil belajar. Instrumen yang digunakan untuk mengumpulkan data hasil belajar berupa soal uraian tentang konsep mol. Soal yang digunakan berjumlah 10 soal. Instrumen yang digunakan untuk mengumpulkan data keterampilan metakognisi berupa angket yang berisi 22 pernyataan. Angket ini diadopsi dari angket yang dikembangkan oleh Schraw \& Dennison (1994) dan disempurnakan oleh instrumen yang dikembangkan oleh Thomas, Anderson, \& Nashon (2004).

Sebelum instrumen digunakan untuk mengambil data dilakukan uji coba instrumen di SMA Negeri 1 Malang. Berdasarkan hasil uji coba dari 18 soal tentang konsep mol,11 soal dinyatakan valid dan 7 soal tidak valid, serta dari ke 18 soal tersebut memiliki tingkat kesukaran sedang-mudah. Instrumen keterampilan metakognisi yang digunakan untuk uji coba sebanyak 22 pernyataan, dari pernyataan tersebut yang dinyatakan valid sebanyak 20 pernyataan dan 2 tidak valid tetapi pernyataan yang tidak valid tersebut dilakukan perbaikan untuk tetap digunakan untuk mengambil data. Soal yang digunakan untuk mengambil data sebanyak 10 sedangkan pernyataan keterampilan metakognisisnya sebanyak 22.

Tabel 1. Pedoman Interpretasi Koefisien Korelasi (Nuryana dan Sugiarto, 2012)

\begin{tabular}{cc}
\hline Koefisien Korelasi & Interpretasi \\
\hline $0,800-1,00$ & Hubungan variabel tinggi \\
$0,600-0,800$ & Hubungan variabel cukup \\
$0,400-0,600$ & Hubungan variabel agak rendah \\
$0,200-0,400$ & Hubungan variabel rendah \\
$0,00-0,200$ & Hubungan variabel sangat rendah \\
\hline
\end{tabular}

Sampel dalam penelitian ini adalah peserta didik kelas X IPA 6 SMA Negeri 2 Mejayan Madiun. Penelitian dilakukan pada bulan februari 2015. Pengerjaan soal konsep mol membutuhkan waktu 70 menit, sedangkan pengisian angket keterampilan metakognisi 20 menit. 
Untuk keperluan analisis, data hasil belajar dan data keterampilan metakognisi beserta tiga komponennya yang meliputi planning skill, monitoring skill, dan evaluation skill mula-mula dideskripsikan secara terpisah. Analisis korelasional kedua data ini dilakukan menggunakan aplikasi SPSS 16.0. Hasil analisis korelasional disajikan pada Tabel 1.

\section{HASIL DAN PEMBAHASAN}

Data penelitian ini adalah hasil belajar konsep mol dan keterampilan metakognisi. Data keterampilan metakognisi selanjutnya dijabarkan menjadi tiga komponen yaitu planning skill, monitoring skill, dan evaluation skill. Hasil belajar konsep mol dan keterampilan metakognisi ditunjukkan dalam Tabel 2.

Tabe1 2. Hasil Belajar Konsep Mol dan Keterampilan metakognisi

\begin{tabular}{ccc}
\hline Aspek & Skor rata-rata & Standar deviasi \\
\hline Hasil belajar & 58,87 & 13,63 \\
Keterampilan metakognisi & 73,68 & 10,47 \\
Planning skill & 76,46 & 10,55 \\
Monitoring skill & 75,78 & 12,96 \\
Evaluation skill & 70,93 & 12,00 \\
\hline
\end{tabular}

Tabel 2 menunjukkan skor rata-rata, standar deviasi untuk hasil belajar konsep mol dan keterampilan metakognisi beserta 3 komponennya yang meliputi planning skill, monitoring skill, dan evaluation skill. Hasil tersebut kemudian dicari korelasinya menggunakan pearson corelation pada aplikasi SPSS 16.0. Sebelum data tersebut dianalisis dilakukan uji prasyarat yang meliputi uji normalitas dan uji linearitas. Berdasarkan uji normalitas menunjukkan bahwa kedua data terdistribusi normal. Hal ini karena nilai signifikasinya sebesar 0,200. Data dikatan terdistribusi normal apabila nilai signifikasinya lebih besar dari taraf signifikasi yaitu 0,05. Uji linearitas menunjukkan bahwa kedua data linear. Hal ini dikarenakan nilai $\mathrm{F}$ hitungnya sebesar 1,2. Hasil dari analisis pearson corelation adalah sebagai berikut.

Tabel 3. Hasil Analisis Korelasi Data Penelitian

\begin{tabular}{cc}
\hline Variabel & Koefisien korelasi (r) \\
\hline Keterampilan metakognisi-hasil belajar & 0,609 \\
Planning skill-hasil belajar & 0,539 \\
Monitoring skill-hasil belajar & 0,523 \\
Evaluation skill-hasil belajar & 0,615 \\
\hline
\end{tabular}

Tabel 3 menunjukkan hubungan antar variabel. Pertama adalah korelasi antara variabel keterampilan metakognisi dengan hasil belajar. Koefisien antar kedua variabel tersebut adalah 0,609 yang menunjukkan bahwa terdapat hubungan antar kedua variabel dengan kategori yang cukup. Berdasarkan nilai $\mathrm{r}$ tersebut dapat dicari seberapa besar pengaruh keterampilan metakognisi terhadap hasil belajar yaitu 37,08\%. Pengaruh keterampilan metakognisi terhadap hasil belajar peserta didik ditunjukkan oleh Gambar 1. 


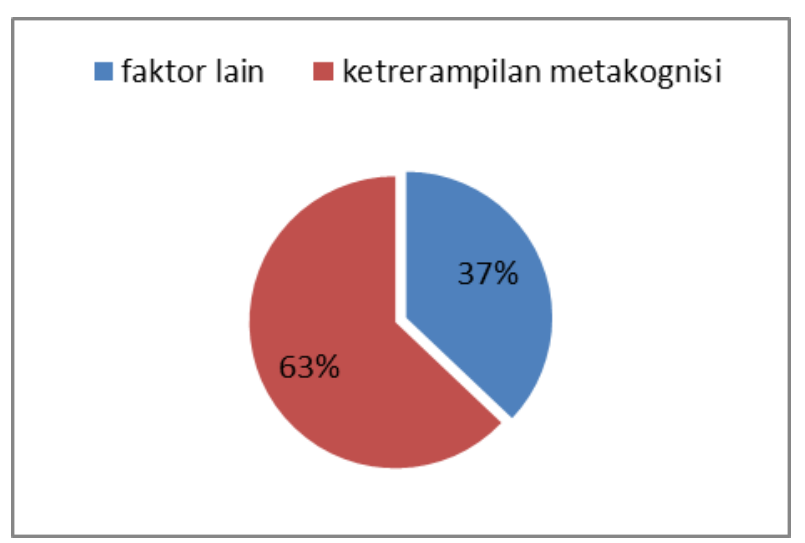

Gambar 1. Pengaruh Keterampilan Metakognisi Terhadap Hasil Belajar

Kedua korelasi antara planning skill dengan hasil belajar. Berdasarkan analsis menggunakan person corelation diperoleh nilai $\mathrm{r}$ sebesar 0,539. Artinya bahwa terdapat hubungan antara planning skill dengan hasil belajar dengan kategori agak rendah. Berdasarkan nilai $r$ tersebut dapat dicari seberapa besar pengaruh planning skill terhadap hasil belajar yaitu 29,05\%. Korelasi yang ketiga yaitu antara variabel monitoring skill dengan hasil belajar. Nilai $r$ yang diperoleh adalah 0,523. Artinya bahwa terdapat hubungan antara monitoring skill dengan hasil belajar dengan kategori agak rendah. Berdasarkan nilai $\mathrm{r}$ tersebut dapat dicari seberapa besar pengaruh monitoring skill terhadap hasil belajar yaitu 27,35\%. Korelasi yang keempat yaitu antara variabel evaluation skill dengan hasil belajar. Nilai $\mathrm{r}$ yang diperoleh sebesar 0,615. Artinya terdapat hubungan yang cukup antara monitoring skill dengan hasil belajar. Berdasarkan nilai $r$ tersebut dapat dicari seberapa besar pengaruh evaluation skill terhadap hasil belajar yaitu sebesar 37,82. Pengaruh komponen keterampilan metakognisi terhadap hasil belajar disajikan pada gambar 2 .

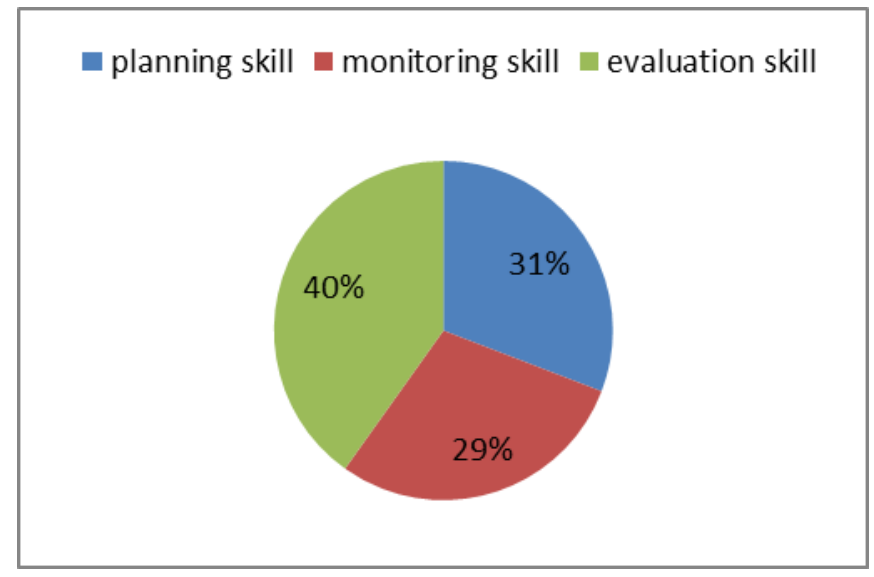

Gambar 2. Pengaruh Komponen Keterampilan Metakognisi Terhadap Hasil Belajar

Hasil penelitian ini menunjukkan bahwa keterampilan metakognisi merupakan salah satu faktor yang dapat meningkatkan hasil belajar. Hal ini dikarenakan adanya tiga komponen dalam keterampilan metakognisi tersebut. Komponen pertama adalah planning skill, adanya komponen ini menyebabkan peserta didik melakukan perencanaan terhadap hal-hal yang akan mereka lakukan sebelum mereka melakukan suatu kegiatan, misalkan dalam memecahkan masalah. Masalah yang disajikan dalam penelitian ini 
berkaitan dengan materi konsep mol. Komponen dalam planning skill memiliki kecocokan dengan karakteristik materi konsep mol. Menyelesaikan masalah yang berkaitan dengan konsep mol diperlukan adanya perencanaan.

Materi konsep mol berisi konsep-konsep yang saling berhubungan. Menyelesaikan suatu soal yang berhubungan dengan konsep mol dibutuhkan adanya suatu rencana. Adanya rencana ini akan sangat membantu seseorang dalam menyelesaikan masalah tersebut. Apabila kegiatan ini dapat dilakukan dengan baik maka kerja yang dilakukan seseorang akan lebih terstruktur karena mereka telah memiliki arah dan tujuan dalam melakukan suatu kegiatan, selain itu dalam hal penggunaan waktunyapun akan lebih efektif dan efisien.

Komponen kedua adalah monitoring skill. Komponen ini berhubungan dengan pemeriksaan serta pemantauan terhadap hal-hal yang seseorang lakukan. Komponen ini sangat diperlukan oleh seseorang ketika mengadapi suatu permasalahan yang berkaitan dengan materi konsep mol. Monitoring skill akan mempermudah peserta didik untuk dapat menggabungkan antara satu konsep dengan konsep yang lain saat memecahkan masalah. Monitoring skill juga akan memudahkan seseirang dalam menjalankan setiap langkah yang telah dirancang sebelumnya. Tahap ini menuntut seseorang untuk teliti dalam melaksanakan setiap langkah dalam kegiatan yang dilakukan.

Komponen ketiga adalah evaluation skill yaitu suatu kegiatan yang digunakan untuk melihat hasil dari kerja yang telah dilakukan. Adanya komponen ini menuntut peserta didik untuk bisa menilai apa yang telah dilakukan, dan menilai keberhasilannya dalam melaksanakan hal apa saja yang telah dirancang sebelumnya. Evaluation skill ini memiliki kecocokan dengan komponen dalam materi konsep mol. Menyelesaikan masalah yang berkaitan dengan konsep mol dibutuhkan adanya ketelitian karena materi ini sebagian besar berisi tentang perhitungan. Apabila ketiga komponen ini dapat diaplikasikan secara baik saat peserta didik memecahkan masalah maka kemungkinan seseorang untuk mendapatkan nilai yang tinggi sangatlah besar.

Berdasarkan tiga komponen tersebut yang memiliki hubungan paling kuat adalah evaluation skill. Hal ini dikarenakan seseorang sudah terbiasa dalam melaksanakan penilaian terhadap apa yang mereka lakukan. Hal ini dikarenakan adanya tahap ini menyebabkan seseorang dapat memahami apa yang ada pada diri mereka yang berkaitan dengan pemahaman materi. Komponen ini membuat seseorang bisa tahu apa yang belum dimengerti dan apa yang sudah dimengerti dengan baik tentang konsepkonsep dalam materi tersebut. Dengan mereka tahu maka mereka akan berusaha untuk mengulang mempelajari konsep yang belum dimengerti tersebut sampai dia benarbenar bisa memahaminya dengan baik, sehingga mereka akan mendapatkan pemahaman yang utuh terhadap konsep-konsep dalam materi tersebut.

\section{KESIMPULAN}

Berdasarkan hasil analisis data dan pembahasan dapat disimpulkan (1) Keterampilan metakognisi peserta didik kelas X SMA Negeri 2 Mejayan Madiun adalah 73,68\%; (2) Hasil belajar konsep mol peserta didik kelas X SMA Negeri 2 Mejayan Madiun adalah 58,87\%; (3) Planning skill peserta didik kelas X SMA Negeri 2 Mejayan Madiun adalah $76,46 \%$; (4) Monitoring skill peserta didik kelas X SMA Negeri 2 Mejayan Madiun adalah $75,78 \%$; (5) Evaluation skill peserta didik kelas X SMA Negeri 2 Mejayan Madiun adalah 
70,93\%; dan (6) Terdapat hubungan antara keterampilan metakognisi dengan hasil belajar konsep mol peserta didik kelas X SMA Negeri 2 Mejayan Madiun dengan kategori cukup yaitu dengan koefisien korelasi sebesar 0,609.

Sesuai dengan temuan penelitian, saran yang dapat dikemukakan adalah (1) Bagi peneliti lain yang ingin melakukan penelitian sejenis hendaknya dalam mengukur keterampilan metakognisi peserta didik dapat menggunakan metode tambahan yang dipadukan dengan instrumen Metacognitive Awareness Inventory (MCI) misalnya dengan menggunaka soal yang menuntut peserta didik berfikir kritis, hal ini dimaksudkan agar dapat memperkuat hasil yang diperoleh; (2) Bagi peneliti lain yang ingin menggunakan instrumen Metacognitive Awareness Inventory (MCI) sebagai alat ukur untuk mengukur keterampilan metakognisi, sebaiknya angket untuk mengukur keterampilan metakognisi dibagikan setelah peserta didik selesai mengerjakan soal hasil belajar. Hal ini dimaksudkan agar hasil yang diperoleh lebih baik lagi; dan (3) Guru dapat menggunakan hasil penelitian ini sebagai salah satu reverensi untuk meningkatkan hasil belajar peserta didik, yaitu dengan meningkatkan keterampilan metakognisi peserta didik yang salah satunya adalah dengan menggunakan strategi metakognisi dalam proses pembelajaran.

\section{DAFTAR RUJUKAN}

Biryukov, P. 2009. Metacognitive Aspects of Solving Combinatoric Problems. Journal of Chemical Education. (Online), (http://www.cimt.plymouth.ac.uk/journal/biryukov.pdf), diakses 31 Maret 2014.

Chang, R. 2010. Chemistry 10 th EDITION. America: Mc Graw Hill Higer Education.

Depdiknas. 2007. Kajian Kebijakan Kurikulum Mata Pelajaran IPA. Tidak dipublikasikan: Pusat Kurikulum Badan Penelitian dan Pengembangan Departemen Pendidikan Nasional.

Eronika, S. 2012. Pengaruh Penerapan Model Pembelajaran LC 5E terhadap Prestasi Belajar Peserta didik Kelas X SMA Negeri 1 Batu Tabun Ajuran 2012/2013 pada Materi Stokiometri. Skripsi tidak diterbitkan. Malang: PPs UM.

Hidayat, S. \& Madya, W. Psikology Pendidikan. Jumal Pendidikan. (Online), (http://scholar.google.co.id/scholar?q=FAKTOR-

FAKTOR+YANG+MEMPENGARUHI+HASIL+belajar\&btnG $=\& h l=i d \& a s \_s d t=0 \% 2$ C5), diakses 29 September 2014.

Hitipeuw, I. 2009. Belajar dan Pembelajaran. Malang: Fakultas Ilmu Pendidikan Universitas Negeri Malang.

Iin, Y. \& Sugiarto, B. 2012. Korelasi antara Keterampilan Metakognitif dengan Hasil Belajar Peserta didik di SMA Negeri 1 Dawarblandong Mojokerto. Jurnal Pendidikan Kimia, 1 (2). (Online), (http://www.scribd.com/doc/118556465/korelasi-antara-keterampilanmetakognitif-dengan-hasil-belajar-peserta didik-di-sman-1-dawarblandongmojokerto\#download), diakses 4 September 2014.

Kaberman, Z. \& Dori, Y.J. 2008. Metacognition in Chemical Education: Question Posing in the Case-Based Computerized Learning Environment. International Journal of Science Education. (Online), (http://eric.ed.gov/?id=EJ852826), diakses 16 Maret 2014.

Kusuma, E.E. 2013. Perbedaan Hasil Belajar Peserta didik antara Penerapan Model LC 5E dengan Ekspositori pada Materi Konsep Mol dan Stokiometri Kelas X SMA Negeri 2 Batu. Skripsi tidak diterbitkan. Malang: PPs UM.

Laskey, M.L., Hetzel, C.J. 2010. Self-Regulated Learning, Metacognition, and Soft Skills: the 21st Century Learner. International Journal of Science Education. (Online), 
(http:/ / eric.ed.gov/?q=Self-

regulated+Learning $\% 2 \mathrm{C}+$ Metacognition $\% 2 \mathrm{C}+$ and + Soft + Skills $\% 3 \mathrm{~A}+$ The +21 st + Century

+Learner), diakses 16 Maret 2014.

Livingston, J.A. 1997. Metacognition: an Overview. International Journal of Science Education.

(Online), (http://www.gse.buffalo.edu), diakses 19 April 2014.

Mathabathe, K.C. \& Potgieter, M. 2014. Metacognitive Monitoring and Learning Gain in Foundation Chemistry. The Royal Socety of Chemistry Journal, (Online), 15: 94-104, ( http://pubs.rsc.org/en/content/articlelanding/2014/rp/c3rp00119a\#!divAbstract), diakses 20 Maret 2014.

Nuryana, E. \& Sugiarto, B. 2012. Hubungan Keterampilan Metakognisi dengan Hasil Belajar Peserta didik pada Materi Reaksi Reduksi Oksidasi (Redoks) Kelas X-1 SMA Negeri 3 Sidoarjo. Jurnal Pendidikan Kimia, 1 (1). (Online), (http://www.scribd.com/doc/118555169/hubungan-keterampilan-metakognisi-denganhasil-belajar-peserta didik-pada-materi-reaksi-reduksi-oksidasi-redoks-kelas-x-1-smanegeri-3-sidoarjo-THE-RELATIO\#download), diakses 4 September 2014.

Rahayuningsih, R., Masykuri, M. \& Utami, B. 2012. Penerapan Siklus Belajar 5E LC Disertai Peta Konsep untuk Meningkatkan Kualitas Proses dan Hasil Belajar Kimia pada Materi Kelarutan dan Hasil Kali Kelarutan Kelas XI IPA SMA Negeri 1 Kartasura Tahun Pelajaran 2011/2012. Jurnal Pendidikan Kimia, 1(1). (Online), (http://eprints.uns.ac.id/11423/1/331\%2D1697\%2D1\%2DPB.pdf), diakses 4 Mei 2015.

Rahman, S. \& Phillips, J.A. 2006. Hubungan antara Kesedaran Metakognisi, Motivasi dan Pencapaian Akademik Pelajar Universiti. Jurnal Pendidikan, (Online), 31 (1): 21-39, (http://202.185.40.50/penerbit/jurnal_pdf/jpend31_02.pdf), diakses 9 September 2014.

Rickey, D. \& Stacy, A.M. 2000. The Role of Metacognition in Learning Chemistry. Journal of Chemical Education, 77(7). (Online), (http:/ / eric.ed.gov/?q= the+role+of + metacognition + in +learning + Chemistry), diakses 16 Maret 2014.

Schraw, G. \& Dennison, R.S. 1994. Assessing Metacognitive Awareness. Contemporary Educational Psychology, (Online), 19 (1): 460-475, (http:/ / www.google.com/search?q=Metacognitive + Awareness + Inventory + \&ie $=$ utf$8 \& o e=$ utf- $8 \&$ aq $=$ t\&rls $=$ org. mozilla:en-US:official\&client $=$ firefox-a), diakses 5 Oktober 2014.

Silberberg, M.S. 2009. Chemistry Fifth Edition the Molekular Nature of Matter and Change. America: Mc Graw Hill Higer Education.

Thomas, G., Anderson D. \& Nashon, S. 2004. Development of an Instrument Designed to Investigate Elements of Science Students's Metacognition, Self- Efficacy and Learning Processes: The SEMLI-S. International Journal of Science Education, (Online), 30 (13): 1701 1724, (bttp:/ / eric.ed.gov/ ?id=EJ812412), diakses 25 Oktober 2014.

Utomo, S. 2015. Prestasi Belajar Kimia Peserta Didik SMA Negeri 2 Mejayan Madiun dari Tahun ke Tahun. Personal Communication. 